\title{
ОСОБЛИВОСТІ ЕКСТЕР'ЄРУ КОРІВ ЧОРНО-РЯБОЇ ХУДОБИ РІЗНОГО ПОХОДЖЕННЯ ЗА ПРОМІРАМИ ТА ІНДЕКСАМИ БУДОВИ ТІЛА
}

\author{
Хмельничий Леонтій Михайлович \\ доктор сільськогосподарських наук, професор \\ Сумський національний аграрний університет \\ ORCID: 0000-0001-5175-1291 \\ E-mail: khmelnychy@ukr.net
}

Карпенко Богдан Миколайович аспірант, спеціальність 204-ТВППТ

Сумський національний аграрний університет ORCID: 0000-0002-9942-5863

E-mail: karpenkobogdan95@gmail.com

Дослідження з оцінки корів української чорно-рябої молочної та голштинської порід за промірами будови тіла та вимені проведені у стаді господарства ПП „Буринське” Підліснівської фрілії Сумського району. Мінливість промірів корів різного походження у віковій динаміці лактацій засвідчили міжпородну мінливість з різним ступенем достовірності різниці між показниками оцінюваних статей будови тіла. За оцінкою промірів у віці першої, другої, третьої та старше лактації кращими показниками відрізнялися корови голштинської породи. Мінливість та рівень індексів будови тіла на сучасному етапі селекції у віковій динаміці лактацій корів української чорно-рябої молочної та голштинської порід засвідчили позитивну динаміку формування екстер'єру тварин цієї худоби у напрямку молочного типу з кращими показниками у голштинів вітчизняної селекції. Порівняльний аналіз корів-первісток голштинської та української чорно-рябої молочної породи за промірами морфологічних ознак вимені виявив очевидну перевагу корів голштинської породи. Серед оціненого поголів'я голштинської породи 86 \% корів-первісток мають бажану ванноподібну форму вимені та 92 \% циліндричну фрорму дійок, що більще у порівнянні з українською чорно-рябою молочною породою відповідно на 5 та 6\%. Із ступінчастим вим'ям серед голштинів зустрічається лише 3\% корів, або на 4\% менше ніж серед корів української чорно-рябої молочної породи. Отримані результати досліджень вказують на позитивний селекційний ефект при застосуванні подальшого схрещування корів української чорно-рябої молочної породи з голштинськими плідниками, що призведе до поліпшення розвитку будови тіла та вимені у їхнього потомства.

Ключові слова: голштинська, українська чорно-ряба молочна, корови, екстер'єр, проміри, будова тіла, вим'я.

DOI: https://doi.org/10.32845/bsnau.lvst.2021.4.5

Створення високопродуктивних порід, типів та стад худоби молочного напряму продуктивності, які б характеризувалися міцним здоров'ям та як найтривалішим терміном експлуатації, були відповідним чином пристосовані до вимог машинного доїння, неможливо без систематичної оцінки тварин за екстер'єром [1, 2, 10, 23]. Добір тварин лише за показниками молочної продуктивності веде до ослаблення конституції, появи у стаді тварин з вадами і недоліками будови тіла, що у підсумку призводить до раннього вибуття корів із стада. Ефективність використання у селекційноплемінній роботі оцінки тварин за екстер єром доведено тривалою вітчизняною та світовою практикою.

Процес створення та подальшого удосконалення української чорно-рябої молочної породи грунтувався на цільових параметрах екстер'єру [7]. Особлива увага приділялась формуванню у тварин бажаної форми будови тіла. Тварини місцевих порід, які стали материнською основою створення української чорно-рябої молочної худоби, повинні були успадкувати притаманні поліпшуючій голштинській породі нові екстер'єрні якості молочного типу $[3,6]$.

У селекційно-племінній роботі в процесі удосконалення молочних порід за типом особливе місце займає їхня оцінка за промірами статей екстер'єру, оскільки поряд з показниками молочної продуктивності, екстер'єр $€$ головною селекційною ознакою при удосконаленні будь-якої молочної породи $[4,8,9,10,12,14,16,21]$. Мотивація оцінки корів за використання промірів обґрунтована тим, що дозволяє отримати об'єктивний цифровий вираз розвитку найважливіших частин тіла тварини у будь-який період її життя, провести порівняльний аналіз як окремих тварин, так і в межах їхніх селекційних груп, стад, типів, порід. Використання промірів екстер'єру у їхньому співвідношенні, вираженому величинами індексів, дозволяє скласти уявлення про гармонійність розвитку окремих статей у загальній будові тіла тварин. Наступний аспект вмотивованості мірної оцінки полягає в існуванні зв'язку більшості екстер'єрних промірів з молочною продуктивністю $[10,16]$.

Останнім часом розведення української чорно-рябої молочної породи в Сумському регіоні відрізняється поголовним використанням голштинських плідників на помісному поголів"ї з різноманітною кровністю за голштинською породою. У результаті поглинального (вбирного) схрещування отримано частину поголів'я корів голштинської худоби вітчизняного походження [24].

Встановити динаміку мінливості будови тіла корів української чорно-рябої молочної породи у порівняльному аналізі з вітчизняною голштинською стало мотивуючим чинником та актуальним питанням в аспекті перспективи її селекції.

Матеріали та методи досліджень. Експериментальні дослідження проведені на поголів"ї корів українських чорно-рябої молочної (УЧРМ) та голштинської порід, що розводяться у стаді ПП „Буринське” Підліснівської фрілії Сум- 
ського району. Екстер'єр у досліджуваних тварин вивчали за розвитком основних статей будови тіла, проміри яких брали упродовж 2-5 місяців після отелення за допомогою: мірної палиці - висоту в холці, спині та крижах, глибину та ширину грудей; мірного циркуля - ширину в маклаках, тазостегнових зчленуваннях і в сідничних горбах, навскісну довжину заду; мірної стрічки - навскісну довжину тулуба, обхват грудей та п'ястку. Індекси будови тіла тварин обчислювали через співвідношення відповідних промірів наведених у книгах Е.Я. Борисенка [1] та В.Ф. Красоты и др. [11].

Проміри та візуальну оцінку вимені проводили за 1,01,5 години до вранішнього доїння на 15-90 день після отелення корів. Вимірювання промірів вимені та дійок проводилось у точках, наведених на рис. 1 за допомогою мірної стрічки, циркуля, штангенциркуля та лінійки і виражались у сантиметрах (см).

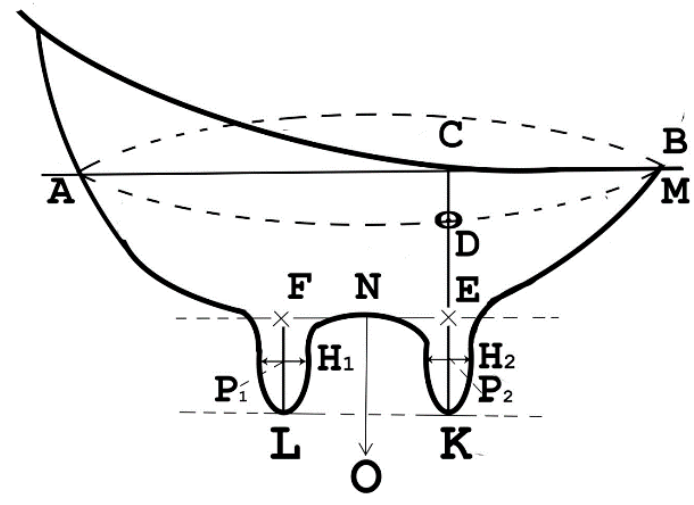

Рис. 1. Точки промірів вимені та дійок

AB - обхват вимені по горизонтальній лінії на рівні переднього краю (стрічкою);

АМ - довжина вимені від задньої випуклості до його переднього краю (циркулем);

СМ - довжина передньої чверті (стрічкою);
D - найбільша ширина вимені над дійками передніх частин (циркулем);

CE - глибина передньої частки - вертикально від черевної стінки до верхньої частини дійки (стрічною);

EK, FL - довжина передніх і задніх дійок (лінійкою); ркулем);

$\mathrm{H}_{1}, \mathrm{H}_{2}$ - діаметр передніх та задніх дійок (штангенцинійкою);

$\mathrm{P}_{1} \mathrm{P}_{2}$ - відстань між передніми і задніми дійками (лі-

NO - відстань від дна вимені до підлоги (стрічкою).

Умовний об'єм вимені (см³) визначали як добуток обхвату вимені помноженого на глибину його передньої частки.

Надійність отриманих даних оцінювали шляхом обчислення похибок статистичних значень (S.E.) та критеріїв надійності Стьюдента (td). Рівень достовірності класифікували порівняно зі значеннями стандартних критеріїв. Результати вважалися статистично значущими для першого - $\mathrm{P}<0,05\left(^{*}\right)$, другого - $\mathrm{P}<0,01\left(^{* *}\right)$ та для третього - Р $\left.<0,001{ }^{* * *}\right)$ порогу ймовірності. Статистичну обробку експериментальних досліджень проводили методами математичної статистики з використанням формул Е.К. Меркурьевой [15] у середовищі Microsoft Excel.

Результати досліджень. Вивчені нами екстер'єрні особливості корів української чорно-рябої молочної породи у віковій динаміці лактацій у порівнянні з голштинською засвідчили міжпородну мінливість з різним ступенем достовірності різниці між показниками оцінюваних статей будови тіла.

За оцінкою промірів у віці першої лактації отримано міжпородну мінливість за якою кращими показниками відрізнялися корови-первістки голштинської породи, табл. 1.

Таблиця 1

Проміри будови тіла корів-первісток української чорно-рябої молочної та голштинської порід

\begin{tabular}{|c|c|c|c|c|}
\hline \multirow{2}{*}{ Ознака } & \multicolumn{2}{|c|}{ Українська чорно-ряба молочна } & \multicolumn{2}{|c|}{ Голштинська } \\
\hline & $x \pm$ S.E. & $\mathrm{Cv}, \%$ & $x \pm$ S.E. & $\mathrm{Cv}, \%$ \\
\hline Оцінено тварин & \multicolumn{2}{|c|}{158} & \multicolumn{2}{|c|}{124} \\
\hline Проміри, см: висота в: холці & $135,2 \pm 0,31$ & 4,26 & $136,9 \pm 0,39^{* * *}$ & 4,51 \\
\hline крижах & $143,1 \pm 0,24$ & 3,74 & $144,3 \pm 0,27^{\star * \star}$ & 3,83 \\
\hline Глибина грудей за лопатками & $73,7 \pm 0,22$ & 4,68 & $74,9 \pm 0,28^{* \star *}$ & 4,56 \\
\hline Ширина: грудей за лопатками & $43,8 \pm 0,22$ & 5,58 & $45,7 \pm 0,29^{\star * *}$ & 5,88 \\
\hline в маклоках & $51,4 \pm 0,12$ & 3,79 & $52,1 \pm 0,17^{\star * *}$ & 4,31 \\
\hline у кульшах & $48,8 \pm 0,13$ & 3,91 & $50,2 \pm 0,15^{\star * *}$ & 4,06 \\
\hline у сідничних горбах & $35,4 \pm 0,12$ & 4,32 & $36,5 \pm 0,14^{* * *}$ & 5,11 \\
\hline Навскісна довжина: заду & $52,4 \pm 0,13$ & 3,68 & $53,8 \pm 0,16^{\star * *}$ & 4,05 \\
\hline тулуба & $163,7 \pm 0,39$ & 4,17 & $165,1 \pm 0,41^{\star \star *}$ & 4,32 \\
\hline Обхват: грудей за лопатками & $195,4 \pm 0,56$ & 4,57 & $201,2 \pm 0,61^{* \star *}$ & 5,13 \\
\hline п'ястку & $19,2 \pm 0,06^{*}$ & 2,27 & $18,7 \pm 0,08^{* * *}$ & 2,37 \\
\hline
\end{tabular}

Примітка: тут і надалі ${ }^{* * *}$ достовірно при $\mathrm{P}<0,001,{ }^{* *}$ - $\mathrm{P}<0,01$ та * $-\mathrm{P}<0,05$.

Однією із важливих ознак екстер'єру тварини є її висота - об'єднувальний показник розвитку всього організму. За відповідних умов годівлі та утримання максимальний розвиток тварини дозволяє аналогічно реалізувати свої спадкові продуктивні задатки. Мінливість високорослості, так само як і решти інших статей будови тіла, залежить як від генотипових, так і паратипових чинників. Оскільки тварини вирощувалися у однакових умовах, на їхній розвиток впли- нув лише генетичний чинник, який засвідчив про перевагу показників промірів на користь тварин голштинської породи.

За результатами наших досліджень корови-первістки голштинської породи підконтрольного стада суттєво переважають ровесниць української чорно-рябої молочної майже за усіма промірами. Найістотніша і, головним чином, високодостовірна різниця спостерігалася за промірами висоти у холці та крижах (1,7 та 1,2 см; P<0,001), глибини $(1,2$ см; P<0,001) i 
ширини грудей (1,9 см; P<0,001), ширини у маклоках $(0,7$ см; $\mathrm{P}<0,001)$, кульшах $(1,4 \mathrm{~cm} ; \mathrm{P}<0,05)$ і сідничних горбах $(1,1 \mathrm{~cm}$; $\mathrm{P}<0,001)$, навскісної довжини заду $(1,4$ см; $\mathrm{P}<0,001)$ і тулуба $(1,4$ см; P<0,001) та обхвату грудей за лопатками $(5,8$ см; $P<0,001)$. За обхватом п'ястку голштини поступалися ровесницям УЧРМ породи на 0,5 см з достовірністю при $\mathrm{P}<0,05$.

Варто у цьому аспекті наголосити, що раніше відмінною особливістю селекції голштинської породи в США і Канаді був добір корів лише за двома ознаками: молочною продуктивністю і типом будови тіла. При цьому оцінка і добір корів за типом був розпочатий значно раніше, ніж за продуктивністю $[13,18]$. Стан будови тіла сучасної голштинської породи характеризується за висотою у холці корів-первісток 137 см, повновікових 143-145 cм, із глибиною грудей $80 \mathrm{~cm}$, а шириною 55 см [19]. За повідомленням наступних авторів [5] висота у холці голштинських корів-первісток з живою масою 575 кг стано-

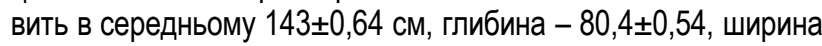

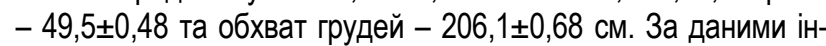
шого автора [14] висота у холці дорослої голштинської корови із живою масою біля 680 кг становить 147 см.

Незважаючи на те, що оцінка корів за промірами вважається достатньо об'єктивним методом, який характеризує їхній екстер'єр, разом з тим вона не дозволяє повною мірою визначити екстер'єрно-конституціональні відмінності розвитку організму у співвідносному розвитку статей. Тому визначені індекси будови тіла, за використання у відповідних формулах промірів, морфологічно зв'язаних між собою статей, надають повне уявлення про гармонійність пропорцій або, навпаки, про певну дисгармонію розвитку організму. За допомогою розрахованих індексів можна встановити продуктивно-типові відмінності в екстер'єрі, вікову мінливість у розвитку окремих ознак та статеві особливості будови тіла тварин.

За оцінкою розрахованих індексів будови тіла корівпервісток піддослідних порід спостерігаються деякі міжпородні відмінності за окремими з них та подібність за іншими, табл. 2.

Індекс довгоногості вказує на відносний розвиток кінцівок тварини у довжину. Цей індекс використовується для характеристики типу конституції, ступеня недорозвиненості тварин. Найбільш високий він у молочної худоби. У тварин в межах однієї породи більша високоногість $€$ одним із показників постембріональної недорозвиненості; навпаки, дуже виражена низьконогість свідчить про недорозвиток тварини в утробному періоді. Із ростом та віком тварин цей індекс зменшується [6]. За нашими дослідженнями величина даного індексу характерна для молочної худоби і не відрізняється між породами.

Менший індекс розтягнутості (формату) властивий молочній худобі. Із віком він збільшується через більш інтенсивний ріст тварин у довжину ніж у висоту. Недостовірна різниця у 0,5\% на користь голштинів свідчить про кращий молочний тип цих тварин.

Тазогрудний індекс, розрахований за співвідношенням ширини грудей до ширини заду в маклоках, достовірно вищий на $2,2 \%(\mathrm{P}<0,001)$ у голштинської худоби через кращий розвиток їхньої грудної клітини у ширину.

Грудний індекс доповнює певним чином тазогрудний, а його вищий рівень у первісток голштинської породи (на $1,6 \% ;$ Р<0,001) свідчить про добрий розвиток у них грудної клітини.

Таблиця 2

Індекси будови тіла корів-первісток української чорно-рябої молочної та голштинської порід

\begin{tabular}{|c|c|c|c|c|}
\hline \multirow{2}{*}{ Назва індексу } & \multicolumn{2}{|c|}{ Українська чорно-ряба молочна } & \multicolumn{2}{|c|}{ Голштинська } \\
\hline & $x \pm$ S.E. & $\mathrm{Cv}, \%$ & $x \pm$ S.E. & $\mathrm{Cv}, \%$ \\
\hline Оцінено тварин & \multicolumn{2}{|c|}{158} & \multicolumn{2}{|c|}{124} \\
\hline Довгоногості & $45,5 \pm 0,11$ & 4,17 & $45,3 \pm 0,13$ & 4,61 \\
\hline Розтягнутості & $121,1 \pm 0,23$ & 3,62 & $120,6 \pm 0,26$ & 3,84 \\
\hline Тазогрудний & $85,2 \pm 0,31$ & 5,66 & $87,7 \pm 0,29^{* \star *}$ & 5,78 \\
\hline Грудний & $59,4 \pm 0,24$ & 4,58 & $61,0 \pm 0,18^{\star \star \star}$ & 4,77 \\
\hline Збитості & $120,1 \pm 0,21$ & 3,82 & $121,5 \pm 0,24^{\star * \star}$ & 3,91 \\
\hline Перерослості & $105,8 \pm 0,11$ & 2,16 & $105,4 \pm 0,13$ & 2,28 \\
\hline Шилозадості & $145,2 \pm 0,24$ & 3,11 & $142,7 \pm 0,27^{\star * *}$ & 3,66 \\
\hline Костистості & $14,2 \pm 0,05$ & 3,21 & $13,7 \pm 0,07^{\star \star *}$ & 3,58 \\
\hline Масивності & $144,5 \pm 0,28$ & 3,64 & $146,9 \pm 0,26^{* * *}$ & 3,87 \\
\hline Глибокогрудості & $54,5 \pm 0,09$ & 3,71 & $54,7 \pm 0,11$ & 4,09 \\
\hline Формату тазу & $96,9 \pm 0,12$ & 2,65 & $96,4 \pm 0,14$ & 2,77 \\
\hline
\end{tabular}

Індекс збитості або компактності є добрим показником розвитку маси тіла і він вищий у голштинських тварин на 1,4 одиниці $(\mathrm{P}<0,001)$.

Індекс перерослості, визначений через співвідношення висоти у крижах до висоти в холці, являється добрим показником росту і розвитку організму у постембріональний період і не відрізняється у наших дослідженнях міжпородною мінливістю.

Про рівень співвідношення ширини в маклоках до ширини у сідничних горбах свідчить величина індексу шилозадості. Він $є$ показником розвитку заду у ширину і з віком збільшується, так як кістки, що визначають ширину у маклоках ростуть довше ніж у сідничних горбах. Достовірна різниця за да- ним індексом на користь голштинських первісток у 2,5\% ( $\mathrm{P}<0,001)$ свідчить про ширші родові шляхи через вищий показник ширини заду у сідничних горбах.

Про відносний розвиток скелету дає уявлення індекс костистості. Чим менший показник цього індексу, тим тонший кістяк оцінюваної тварини, і навпаки. Величина індексу костистості у первісток голштинської породи $(14,2 \%)$ через незначну його мінливість достовірно вища на 0,5\% (P<0,001) ніж у ровесниць української чорно-рябої молочної породи, що свідчить про кращий розвиток скелету голштинів у напрямку молочного типу.

Відносний розвиток тулуба великої рогатої худоби досить добре характеризується числовим співвідношенням 
обхвату грудей до висоти у холці, яке має назву індексу масивності. За результатами наших досліджень цей індекс вищий на 2,4\% (P<0,001) у тварин голштинської породи.

Індекс глибокогрудості також характеризує розвиток грудної клітини. Повідомляється [1], що якщо співвідношення промірів глибини грудей за лопатками до висоти у холці перевищує 50\%, у такому разі груди глибокі, тоді як за меншого співвідношення грудна клітина вважається мілкою. Корови-первістки обох порід характеризуються достатньо глибокими грудьми з незначною мінливістю індексу глибокогрудості у межах 54,5 та 54,7 \% на користь голштинів.

Індекс формату тазу доповнює індекс шилозадості і характеризує розвиток заду в ширину через співвідношення ширини у кульшових зчленуваннях до ширини у маклоках. У тварин з широким задом менша числова різниця між співвідношенням цих промірів виражена вищим індексом.

Рівень показників промірів корів у межах підконтрольних порід узятих у віці другої, третьої і старше лактацій, дозволяє зробити узагальнюючий висновок про те, що формування у них будови тіла відрізняється загалом позитивною динамікою розвитку, табл. 3 та 4.

Наступний узагальнюючий висновок полягає у тому, що величини промірів статей будови тіла корів у віці другої та третьої і старше лактацій свідчать про те, що тварини обох порід за своїм ростом і розвитком відносяться до крупних тварин.

Разом з тим, порівняльний міжпородний аналіз показує на незначну, але статистично достовірну перевагу корів голштинської породи над одновіковими тваринами української чорно-рябої молочної худоби крім обхвату п'ястку, табл. 3. Різниця між промірами у віці другої лактації склала за: висотою у холці 1,4 см, висотою у крижах 2,3 , глибиною грудей 2,0, шириною грудей 2,1, шириною у маклоках 1,0, кульшах 1,1 та сідничних горбах 1,1, навкісною довжиною заду 1,2 та тулуба 1,9 і обхватом грудей 6,0 см, поступаючись за обхватом п'ястку на $0,5 \mathrm{~cm}$.

Отримані аналогічні результати міжпородного порівняння промірів у віці третьої та старше лактацій, табл. 4. Різниця між промірами у даному віці на користь голштинів склала за: висотою у холці 2,0 см, висотою у крижах 2,1, глибиною грудей 1,8, шириною грудей 2,0, шириною у маклоках 1,6 , кульшах 2,4 та сідничних горбах 1,2 , навкісною довжиною заду 1,7 та тулуба 2,1 і обхватом грудей 4,1 см, поступаючись за обхватом п'ястку на 0,5 cм.

Індекси будови тіла корів підконтрольних порід, розраховані за даними промірів другої лактації, наведені у табл. 5. Вікова мінливість визначених індексів співвідноситься зі зміною росту та розвитку корів у даній віковій категорії. Міжпородна різниця майже кореспондується з даними порівнянь у віці першої лактації. Хоча вікова нерівномірність росту спричинила окремі відмінності за індексами у віці другої лактації, згідно яких у корів голштинської породи зменшився індекс довгоногості порівняно з первістками на 0,88 одиниць, індекс збитості зріс на 0,8, шилозадості зменшився на 1,0, а глибокогрудості зріс на 0,88 одиниці.

Проміри будови тіла корів української чорно-рябої молочної та голштинської порід у віці другої лактації

\begin{tabular}{|c|c|c|c|c|}
\hline \multirow{2}{*}{ Ознака } & \multicolumn{2}{|c|}{ Українська чорно-ряба молочна } & \multicolumn{2}{|c|}{ Голштинська } \\
\hline & $x \pm$ S.E. & $\mathrm{Cv}, \%$ & $x \pm$ S.E. & $\mathrm{Cv}, \%$ \\
\hline Оцінено тварин & \multicolumn{2}{|c|}{171} & \multicolumn{2}{|c|}{154} \\
\hline Проміри, см: висота в: холці & $136,8 \pm 0,27$ & 3,54 & $138,2 \pm 0,32^{\star \star *}$ & 4,13 \\
\hline крижах & $145,3 \pm 0,22$ & 3,38 & $147,6 \pm 0,25^{\star \star *}$ & 3,43 \\
\hline Глибина грудей за лопатками & $74,8 \pm 0,21$ & 4,11 & $76,8 \pm 0,27^{\star \star *}$ & 4,24 \\
\hline Ширина: грудей за лопатками & $44,7 \pm 0,19$ & 4,73 & $46,8 \pm 0,25^{* * *}$ & 4,96 \\
\hline в маклоках & $52,6 \pm 0,11$ & 3,41 & $53,6 \pm 0,14^{* * *}$ & 4,73 \\
\hline у кульшах & $50,7 \pm 0,12$ & 3,54 & $51,8 \pm 0,15^{* * *}$ & 3,61 \\
\hline у сідничних горбах & $36,6 \pm 0,13$ & 4,04 & $37,7 \pm 0,16^{* * *}$ & 4,72 \\
\hline Навскісна довжина: заду & $53,7 \pm 0,12$ & 3,42 & $54,9 \pm 0,17^{\star * *}$ & 3,62 \\
\hline тулуба & $165,5 \pm 0,29$ & 4,03 & $167,4 \pm 0,32^{* * *}$ & 4,15 \\
\hline Обхват: грудей за лопатками & $198,6 \pm 0,44$ & 4,12 & $204,6 \pm 0,52^{* * *}$ & 4,29 \\
\hline п'ястку & $19,5 \pm 0,05^{\star \star *}$ & 2,05 & $19,0 \pm 0,06$ & 2,14 \\
\hline
\end{tabular}

Проміри будови тіла корів української чорно-рябої молочної

Таблиця 4 та голштинської порід у віці третьої та старше лактацій

\begin{tabular}{|c|c|c|c|c|}
\hline \multirow{2}{*}{ Ознака } & \multicolumn{2}{|c|}{ Українська чорно-ряба молочна } & \multicolumn{2}{|c|}{ Голштинська } \\
\hline & $x \pm$ S.E. & $\mathrm{Cv}, \%$ & $x \pm$ S.E. & $\mathrm{Cv}, \%$ \\
\hline Оцінено тварин & \multicolumn{2}{|c|}{189} & \multicolumn{2}{|c|}{166} \\
\hline Проміри, см: висота в: холці & $137,8 \pm 0,22$ & 3,32 & $139,8 \pm 0,27^{* * *}$ & 3,95 \\
\hline крижах & $146,4 \pm 0,19$ & 3,14 & $148,5 \pm 0,24^{* * *}$ & 3,36 \\
\hline Глибина грудей за лопатками & $78,6 \pm 0,20$ & 3,92 & $80,4 \pm 0,26^{* * *}$ & 4,27 \\
\hline Ширина: грудей за лопатками & $46,8 \pm 0,16$ & 4,25 & $48,8 \pm 0,22^{\star \star *}$ & 4,64 \\
\hline в маклоках & $55,1 \pm 0,12$ & 3,13 & $56,7 \pm 0,15^{\star \star *}$ & 4,04 \\
\hline у кульшах & $53,2 \pm 0,10$ & 3,07 & $55,6 \pm 0,14^{* * *}$ & 3,72 \\
\hline у сідничних горбах & $37,6 \pm 0,12$ & 3,62 & $38,8 \pm 0,15^{\star \star *}$ & 4,31 \\
\hline Навскісна довжина: заду & $54,2 \pm 0,09$ & 3,16 & $55,9 \pm 0,12^{* * *}$ & 3,56 \\
\hline тулуба & $171,1 \pm 0,21$ & 3,64 & $173,2 \pm 0,26^{\star \star *}$ & 3,95 \\
\hline Обхват: грудей за лопатками & $202,5 \pm 0,36$ & 3,27 & $206,6 \pm 0,44^{* * *}$ & 3,87 \\
\hline п'ястку & $20,1 \pm 0,05^{\star \star \star}$ & 1,87 & $19,6 \pm 0,06$ & 2,11 \\
\hline
\end{tabular}


За наведеними у табл. 6 індексами будови тіла повновікових корів також спостерігається міжпородна різниця, яка відрізняються від попередніх через зміну промірів у процесі росту, розвитку та фізіологічного стану тварин.

У повновікових корів голштинської породи у порівнянні з однолітками української чорно-рябої молочної спос- терігалася достовірна різниця у бік зменшення таких індексів як довгоногості (-0,5 од.), розтягнутості $(-0,9$ од.) та костистості (-1,3 од.) i, навпаки, у бік зростання - тазогрудного (1,2 од.), грудного (1,1 од.), збитості $(0,9)$, глибокогрудості $(0,5$ од.) та фрормату тазу (1,5 од).

Індекси будови тіла корів української чорно-рябої молочної

Таблиця 5 та голштинської порід у віці другої лактації

\begin{tabular}{|c|c|c|c|c|}
\hline \multirow{2}{*}{ Назва індексу } & \multicolumn{2}{|c|}{ Українська чорно-ряба молочна } & \multicolumn{2}{|c|}{ Голштинська } \\
\hline & $x \pm$ S.E. & $\mathrm{Cv}, \%$ & $x \pm$ S.E. & $\mathrm{Cv}, \%$ \\
\hline Оцінено тварин & \multicolumn{2}{|c|}{171} & \multicolumn{2}{|c|}{154} \\
\hline Довгоногості & $45,3 \pm 0,09$ & 3,52 & $44,4 \pm 0,11^{* \star *}$ & 3,74 \\
\hline Розтягнутості & $121,0 \pm 0,19$ & 3,43 & $120,3 \pm 0,22^{*}$ & 3,51 \\
\hline Тазогрудний & $85,0 \pm 0,25$ & 4,78 & $87,3 \pm 0,23^{\star \star *}$ & 4,63 \\
\hline Грудний & $59,8 \pm 0,21$ & 4,13 & $60,9 \pm 0,19^{* * *}$ & 4,22 \\
\hline Збитості & $120,0 \pm 0,18$ & 3,41 & $122,2 \pm 0,21^{* \star *}$ & 3,77 \\
\hline Перерослості & $106,2 \pm 0,10$ & 2,03 & $106,8 \pm 0,12^{\star * *}$ & 2,11 \\
\hline Шилозадості & $143,7 \pm 0,24$ & 2,92 & $142,2 \pm 0,24^{\star \star \star}$ & 3,31 \\
\hline Костистості & $14,3 \pm 0,05$ & 3,04 & $13,7 \pm 0,07^{\star \star \star}$ & 3,14 \\
\hline Масивності & $145,2 \pm 0,25$ & 3,36 & $148,0 \pm 0,29^{\star \star \star}$ & 3,55 \\
\hline Глибокогрудості & $54,7 \pm 0,08$ & 3,52 & $55,6 \pm 0,10^{\star \star *}$ & 3,79 \\
\hline Формату тазу & $96,4 \pm 0,11$ & 2,35 & $96,6 \pm 0,13$ & 2,45 \\
\hline
\end{tabular}

Індекси будови тіла корів української чорно-рябої молочної

Таблиця 6 та голштинської порід у віці третьої і старше лактацій

\begin{tabular}{|c|c|c|c|c|}
\hline \multirow{2}{*}{ Назва індексу } & \multicolumn{2}{|c|}{ Українська чорно-ряба молочна } & \multicolumn{2}{|c|}{ Голштинська } \\
\hline & $x \pm$ S.E. & $\mathrm{Cv}, \%$ & $x \pm$ S.E. & $\mathrm{Cv}, \%$ \\
\hline Оцінено тварин & \multicolumn{2}{|c|}{189} & \multicolumn{2}{|c|}{166} \\
\hline Довгоногості & $43,0 \pm 0,09$ & 3,55 & $42,5 \pm 0,12^{\star \star \star}$ & 4,11 \\
\hline Розтягнутості & $124,2 \pm 0,21$ & 3,27 & $123,9 \pm 0,24$ & 3,45 \\
\hline Тазогрудний & $84,9 \pm 0,27$ & 5,33 & $86,1 \pm 0,21^{\text {** }}$ & 5,41 \\
\hline Грудний & $59,5 \pm 0,28$ & 3,89 & $60,6 \pm 0,23^{* *}$ & 4,22 \\
\hline Збитості & $118,4 \pm 0,20$ & 3,63 & $119,3 \pm 0,22^{* *}$ & 3,77 \\
\hline Перерослості & $106,2 \pm 0,12$ & 2,24 & $106,2 \pm 0,14$ & 2,31 \\
\hline Шилозадості & $146,5 \pm 0,26$ & 3,19 & $146,1 \pm 0,29$ & 3,74 \\
\hline Костистості & $15,3 \pm 0,06$ & 3,28 & $14,0 \pm 0,05^{\star * *}$ & 3,42 \\
\hline Масивності & $147,0 \pm 0,24$ & 3,42 & $147,8 \pm 0,27^{*}$ & 3,51 \\
\hline Глибокогрудості & $57,0 \pm 0,07$ & 3,22 & $57,5 \pm 0,10^{\star * *}$ & 3,88 \\
\hline Формату тазу & $96,6 \pm 0,11$ & 2,43 & $98,1 \pm 0,13^{* * *}$ & 2,67 \\
\hline
\end{tabular}

Зміна індексів будови тіла у повновікових корів в порівнянні з первістками у бік зменшилися спостерігається за індексом довгоногості на 2,5 у корів української чорно-рябої молочної та на 2,8 - голштинської порід та збитості відповідно на 1,7 та 2,2 од. Що стосується індексу довгоногості то результат закономірний, оскільки розвиток грудей у глибину з віком вищий ніж ріст у висоту. Зростання індексу розтягнутості у порівнянні з первістками, відповідно на 3,1 та 3,3 одиниці, пояснюється тим, що із віком спостерігається більш інтенсивний ріст тварин у довжину ніж у висоту. Це стосується також індексів масивності та глибокогрудості, які також зросли за аналогічної причини відповідно на 2,5 і 0,9 та 2,5 і 2,8 одиниці.

Таким чином, на сучасному етапі селекції рівень і мінливість промірів та індексів будови тіла у віковій динаміці лактацій корів української чорно-рябої молочної та голштинської порід свідчать загалом про позитивну динаміку формування екстер'єру тварин цієї худоби у напрямку молочного типу $з$ кращими показниками у голштинів вітчизняної селекціï.

Науковий та практичний досвід селекції молочної ху- доби неодноразово підтверджував, що морфологічні ознаки вимені $€$ найбільш важливими і надійними екстер'єрними показниками високої удійності та технологічності корів [17, $20,22,23,25,26]$.

Добір корів у стаді за екстер'єром, особливо за морфологічними та технологічними ознаками вимені, здебільшого здійснюють у віці першої лактації, так само як і оцінку бугаїв-плідників за типом їхніх дочок згідно методики лінійної класифікації. У процесі збільшення розмірів корів у віці другого і наступних отелень у тварин поступово утворюються вікові вади, як опускання вимені за нещільного прикріплення, провисання лінії спини, погіршення постави кінцівок і якості ратиць тощо [3]. Тому повторна оцінка екстер'єру корів другого і старших отелень проводиться уже як виключення, у разі якоїсь селекційної необхідності на кшталт їхнього залучення до групи бугайвиробничих матерів. Саме через це оцінку вимені корів здійснювали після першого отелення.

Визначити наскільки поліпшилися морфологічні ознаки вимені корів-первісток української чорно-рябої молочної породи у результаті поглинання її голштинами стало 
завданням наступних досліджень.

У таблиці 7 наведені результати оцінки морфологічних ознак вимені за промірами у порівнянні двох піддослідних порід. Показники промірів вимені засвідчили перевагу корів-первісток голштинської породи над ровесницями української чорно-рябої молочної за обхватом вимені на 3,2 см $(\mathrm{P}<0,001)$, глибиною передньої частки - 1,4 ( $<<0,01)$, відстанню від дна до землі - 0,8, довжиною передньої чверті 0,5, довжиною вимені - 2,2 ( $<<0,001)$, шириною вимені $-2,1$ $(\mathrm{P}<0,001)$, умовним об'ємом вимені $-280 \mathrm{~cm}^{3}(\mathrm{P}<0,001)$.

Розташування дійок $€$ досить важливою як із селек- ційної точки зору, так і з технологічної. Загалом, розміщення дійок на вим'ї може бути: широке, майже квадратне; широке передніх і зближене задніх; зближене бічних при нормальній відстані між дійками лівого і правого боку; зближене розміщення всіх дійок. Небажана як дуже близька (до 6 см), так і дуже велика (більше 20 см) відстань між вершинами дійок. Дійки, які розташовані на оптимальній відстані (12-16 см), розміщені по центру часток вимені, вертикально спрямовані вниз, циліндричної або конічної форми - найкраще забезпечують вимоги машинного доїння [23].

Характеристика корів-первісток молочної худоби за морфологічними ознаками вимені $(x \pm S . E$.

\begin{tabular}{|c|c|c|c|}
\hline \multirow{2}{*}{\multicolumn{2}{|c|}{ Промір, см }} & \multicolumn{2}{|c|}{ Порода } \\
\hline & & голштинська & українська чорно-ряба молочна \\
\hline \multicolumn{2}{|c|}{ обхват вимені } & $144,7 \pm 0,52^{\star \star \star}$ & $141,5 \pm 0,48$ \\
\hline \multicolumn{2}{|c|}{ глибина передньої частки } & $24,8 \pm 0,33^{* *}$ & $23,4 \pm 0,29$ \\
\hline \multicolumn{2}{|c|}{ відстань від дна до землі } & $62,4 \pm 0,42$ & $61,6 \pm 0,33$ \\
\hline \multicolumn{2}{|c|}{ довжина передньої чверті } & $15,3 \pm 0,29$ & $14,8 \pm 0,25$ \\
\hline \multicolumn{2}{|c|}{ довжина вимені } & $44,5 \pm 0,26^{\star \star \star}$ & $42,3 \pm 0,23$ \\
\hline \multicolumn{2}{|l|}{ ширина вимені } & $35,2 \pm 0,28^{* * *}$ & $33,1 \pm 0,24$ \\
\hline \multicolumn{2}{|c|}{ умовний об'єм вимені, см ${ }^{3}$} & $3589 \pm 49,3^{* * *}$ & $3309 \pm 45,4$ \\
\hline \multirow{2}{*}{ довжина дійок } & передніх & $5,0 \pm 0,10^{* * *}$ & $5,5 \pm 0,08$ \\
\hline & задніх & $4,2 \pm 0,08^{\star *}$ & $4,5 \pm 0,06$ \\
\hline \multirow{2}{*}{ діаметр дійок } & передніх & $2,3 \pm 0,03^{\star *}$ & $2,4 \pm 0,02$ \\
\hline & задніх & $2,2 \pm 0,03^{* *}$ & $2,3 \pm 0,02$ \\
\hline \multirow{3}{*}{ відстань між дійками } & передніми & $17,2 \pm 0,29^{\star \star}$ & $16,1 \pm 0,25$ \\
\hline & задніми & $8,5 \pm 0,19$ & $8,2 \pm 0,15$ \\
\hline & передніми і задніми & $12,6 \pm 0,15^{\star \star \star}$ & $10,9 \pm 0,12$ \\
\hline \multirow{2}{*}{ форма, \% } & ванноподібна & 86 & 81 \\
\hline & чашовидна & 14 & 19 \\
\hline \multirow{2}{*}{ форма дійок, \% } & циліндрична & 92 & 86 \\
\hline & конічна & 8 & 14 \\
\hline \multicolumn{2}{|l|}{ Ступінчасте вим'я, \% } & 3 & 7 \\
\hline
\end{tabular}

За важливими технологічними ознаками вимені, які характеризують розвиток дійок, кращими виявилися коровипервістки голштинської породи. Довжина передніх дійок у корів-первісток голштинської породи була достовірно коротшою на 0,5 cм ( $P<0,001)$, а задніх - на 0,3 cм $(P<0,01)$. Між розташуванням передніх дійок відстань була більшою у корів-первісток голштинської породи на $1,1 \mathrm{~cm}(\mathrm{P}<0,01)$, задніх - 0,3 та між передніми та задніми - 1,7 cм $(P<0,001)$. Діаметр передніх і задніх дійок у голштинських корів зменшився на 0,1 см $(P<0,01)$.

Серед оціненого поголів'я голштинської породи 86 \% корів-первісток мають бажану ванноподібну форму вимені та $92 \%$ - циліндричну форму дійок, що більше у порівнянні 3
учРМ відповідно на 5 та 6\%. Із ступінчастим вим'ям серед голштинів зустрічається лише 3\% корів, або на 4\% менше ніж серед корів УЧРМ.

Отже, порівняльний аналіз корів-первісток голштинської та української чорно-рябої молочної породи за промірами морфологічних ознак вимені виявив очевидну перевагу корів голштинської породи.

Висновки. Отримані результати досліджень вказують на позитивний селекційний ефект при застосуванні подальшого схрещування корів української чорно-рябої молочної породи з голштинськими плідниками, що призведе до поліпшення розвитку будови тіла та вимені у їхнього потомства.

\section{Список використаної літератури:}

1. Борисенко Е. Я. Разведение сельскохозяйственных животных. М.: Колос, 1967. 463 с.

2. Буркат В. П., Полупан Ю. П., Йовенко І. В. Лінійна оцінка корів за типом. К.: Аграрна наука, 2004. 88 с.

3. Гладій М. В., Єфріменко М. Я., Полупан Ю. П., Коваленко Г. С., Черняк Н. Г., Прийма С. В. Українська чорно-ряба молочна порода. У кн.: Селекційні, генетичні та біотехнологічні методи удосконалення і збереження генофондду порід сільськогосподарських тварин. М. В. Гладій, Ю. П. Полупан [та ін.]; за ред.: М. В. Гладія і Ю. П. Полупана; ІРГТ ім. М.В. Зубця НААН. Полтава, ТОВ «Фірма «Техсервіс», 2018. С. 253-267.

4. Даньків В. Я. Створення високопродуктивних стад комбінованого напряму продуктивності в умовах Прикарпаття. Передгірне та гірське землеробство і тваринництво. 2015. Вип. 58 (II). С. 109-113.

5. Ефименко М. Я. Методические рекомендации по созданию нового внутрипородного типа черно-пестрого скота с использованием голштино-фрризских быков. Методические рекомендации по селекции и воспроизводству крупного рогатого скота. К., 1980. С. 36-40. 
6. Ефименко, М. Я. Украинская черно-пестрая молочная порода: генезис, состояние и перспективы селекции. Розведення і генетика тварин. К.: Аграрна наука. 2010. Вип. 44. С. 17-20.

7. Єффіменко М. Я., Рубан С. Ю., Бірюкова О. Д., Братушка Р. В., Коваленко Г. С., Черняк Н. Г., Шаран П. І., Кузебний С. В., Гавриленко М. С., Прийма С. В., Швець Н. В., Гольоса Г. О. Програма селекції української чорно-рябої молочної породи великої рогатої худоби на 2013-2020 роки; за ред. М. Я. Єфіменка. Чубинське, 2013. 56 с.

8. Каратєєва О. І., Лесік І.М. Оцінка екстер'єру основних промірів будови тіла телиць залежно від їх походження. Вісник аграрної науки Причорномор'я. 2020. Вип. 4. С. 79-87.

9. Козир В. С., Мовчан Т. В. Екстер'єрна оцінка та її зв'язок з продуктивністю корів різних порід. Вісник аграрної науки. 2003. № 2. С. 36-38.

10. Кравченко Н. А. Разведение сельскохозяйственных животных. М. : Колос, 1973. 486 с.

11. Красота В. Ф., Лобанов В. Т., Джапаридзе Т. Г. Разведение сельскохозяйственных животных. 2-е изд., перераб. и доп. М.: Колос, 1983. 413 с

12. Кузів М. І. Екстер'єрні особливості корів-первісток української чорно-рябої молочної породи. Вісник Житомирського національного агроекологічного університету. 2014. Т. 3, № 2 (44). С. 270-274.

13. Кузнецов В. М. Сахалинская популяция голштинской породы : монография. Чебоксары: ИД «Среда», 2020. 248 с.

14. Ладика В. І., Хмельничий Л. М. Особливості фенотипової різноманітності корів за екстер'єрним типом в аспекті збереження генофонду бурої худоби. Вісник Сумського національного аграрного університету. Сер. «Тваринництво». 2018. Вип. 2 (34). С. 3-10.

15. Меркурьева Е. К. Генетические основы селекции в скотоводстве. М.: Колос, 1977. 240 с.

16. Полупан Ю. П. Онтогенетичні та селекційні закономірності фрормування господарськи корисних ознак молочної худоби : дис. ... д-ра с.-г. наук : 06.02.01 с. Чубинське Київської обл., 2013. 694 с.

17. Полупан Ю. П., Коваль Т. П. Зв'язок морфологічних особливостей вим'я корів червоної молочної худоби з їхньою молочною продуктивністю. Вісн. аграр. науки. 2006. № 11. С. 49-52.

18. Прохоренко П. Н., Логинов Ж. Г. Голштино-фризская порода скота. Л. : Агропромиздат, 1985. 237 с.

19. Солдатов А. П. Голштинская порода. Полный каталог пород домашних животных. М.: Эксмо-Пресс, 2001. 128 с

20. Ставецька Р., Клопенко Н. Характеристика вим'я корів української чорно-рябої молочної породи за вбирного схрещування. Тваринництво України. 2015. №12 (72). С. 15-20.

21. Федорович В. В., Бабік Н. П. Ваговий та лінійний ріст корів червоної польської породи в умовах західного регіону України. Науковий вісник Львівського національного університету ветеринарної медицини та біотехнологій ім. С. 3. Гжицького. Львів, 2012. Т. 16, № 3 (60), ч. 3. С. 199-205.

22. Хмельничий Л. М. Екстер'єрний тип та продуктивність корів української чорно-рябої молочної породи. Науковотехнічний бюлетень Інституту тваринництва УААН. Харків. 2003. №. 84. С. 142-146.

23. Хмельничий Л. М. Оцінка екстер'єру тварин в системі селекції молочної худоби : монографія. Суми : ВВП "Мрія-1" TOB, 2007. $260 \mathrm{c}$.

24. Хмельничий Л. М., Бардаш Д. О. Показники довголіття корів української червоно-рябої молочної породи залежно від частки спадковості голштинської породи. Вісник Сумського НАУ. Серія «Тваринництво». 2019. Вип. 4(39). C.13-19. DOI: https://doi.org/10.32845/bsnau.lvst.2019.4.2

25. Хмельничий Л. М., Вечорка В. В. Вікова мінливість кореляцій між надоєм та лінійною оцінкою типу корів-первісток українських чорно- та червоно-рябої молочних порід. Технологія виробництва і переробки продуктів тваринництва. Збірник наукових праць БНАУ. Біла Церква. 2014. № 1 (116). С. 84-87.

26. Хмельничий Л. М., Вечорка В. В. Особливості будови тіла корів української чорно-рябої молочної та голштинської порід. Розведення і генетика тварин. К.: Аграрна наука. 2008. Вип. 42. С. 318326.

\section{References:}

1. Borisenko, E. Ya., 1967. Razvedenie sel'skokhozyaystvennykh zhivotnykh [Breeding of farm animals]. Moskva: Kolos.

2. Burkat, V. P., Polupan, lu. P. and Yovenko, I. V., 2004. Liniina otsinka koriv za typom [Linear estimation of cows by type]. Kyiv: Ahrarna nauka.

3. Hladii, M. V., Yefimenko, M. Ya., Polupan, Yu. P., Kovalenko, H. S., Cherniak, N. H. and Pryima, S. V., 2018. Ukrainian Black-and-White dairy breed. In: M.V. Hladii, Yu.P. Polupan, ed. Selektsiini, henetychni ta biotekhnolohichni metody udoskonalennia i zberezhennia henofondu porid silskohospodarskykh tvaryn [Breeding, genetic and biotechnological methods for improving and preserving the gene pool of farm animal breeds]. Poltava, TOV «Firma «Tekhservis», pp. 253-267.

4. Dankiv, V. Ya., 2015. Stvorennia vysokoproduktyvnykh stad kombinovanoho napriamu produktyvnosti v umovakh Prykarpattia [Creation of highly productive herds of the combined direction of productivity in the Carpathian region]. Peredhirne ta hirske zemlerobstvo i tvarynnytstvo, issue 58, pp. 109-113.

5. Efimenko, M. Ya., 1980. Metodicheskie rekomendatsii po sozdaniyu novogo vnutriporodnogo tipa cherno-pestrogo skota $\mathrm{s}$ ispol'zovaniem golshtino-frizskikh bykov [Guidelines for the creation of a new intrabreed type of Black-and-White cattle using Holstein-Friesian bulls]. Metodicheskie rekomendatsii po selektsii i vosproizvodstvu krupnogo rogatogo skota. Kyiv, pp. 36-40.

6. Efimenko, M. Ya., 2010. Ukrainskaya cherno-pestraya molochnaya poroda: genezis, sostoyanie i perspektivy selektsii [Ukrainian Black-and-White dairy breed: genesis, state and prospects of selection]. Rozvedennya i genetika tvarin. K.: Agrarna nauka, issue 44, pp. 17-20.

7. Yefimenko, M. Ya., Ruban, S. Yu., Biriukova, O. D., Bratushka, R. V., Kovalenko, H. S., Cherniak, N. H., Sharan, P.I., Kuzebnyi, S.V., Havrylenko, M. S., Pryima, S. V., Shvets, N. V. and Holosa, H. O., 2013. In: M.Ya. Yefimenko, ed. Prohrama sel- 
ektsii ukrainskoi chorno-riaboi molochnoi porody velykoi rohatoi khudoby na 2013-2020 roky [Breeding program of the Ukrainian Black-and-White dairy breed of cattle for 2013-2020]. Chubynske.

8. Karatieieva, O. I. and Lesik, I. M., 2020. Otsinka eksterieru osnovnykh promiriv budovy tila telyts zalezhno vid yikh pokhodzhennia [Estimation of the conformation of the main body structure measurements of heifers depending on their origin]. Visnyk ahrarnoi nauky Prychornomoria, issue 4, pp. 79-87.

9. Kozyr, V. S. and Movchan, T. V., 2003. Eksterierna otsinka ta yii zviazok z produktyvnistiu koriv riznykh porid [Conformation assessment and its relationship with cow's productivity of different breeds]. Visnyk ahrarnoi nauky, no. 2, pp. 36-38.

10. Kravchenko, N.A., 1973. Razvedenie sel'skokhozyaystvennykh zhivotnykh [Breeding of farm animals]. Moskva: Kolos.

11. Krasota, V. F., Lobanov, V. T. and Dzhaparidze, T. G., 1983. Razvedenie sel'skohozjajstvennyh zhivotnyh. 2-e izd., pererab. $i$ dop. [Breeding of farm animals. 2nd ed., revised and added]. Moskva: Kolos.

12. Kuziv, M. I., 2014. Eksterierni osoblyvosti koriv-pervistok ukrainskoi chorno-riaboi molochnoi porody [Conformation features of the cows-firstborn of Ukrainian Black-and-White dairy breed]. Visnyk Zhytomyrskoho natsionalnoho ahroekolohichnoho universytetu, no. 2(44), pp. 270-274.

13. Kuznetsov, V. M., 2020. Sakhalinskaya populyatsiya golshtinskoy porody: monografiya [Sakhalin population of the Holstein breed: monograph]. Cheboksary: ID «Sreda».

14. Ladyka, V. I. and Khmelnychyi, L. M., 2018. Osoblyvosti fenotypovoi riznomanitnosti koriv za eksteriernym typom v aspekti zberezhennia henofondu buroi khudoby [Features of the phenotypic diversity of cows by conformation type in the aspect of preserving the gene pool of Brown cattle]. Visnyk Sumskoho NAU: seriia "Tvarynnytstvo", issue 2(34), pp. 3-10.

15. Merkur'eva, E. K., 1977. Geneticheskie osnovy selektsii v skotovodstve [Genetic bases of selection in the animal husbandry]. Moskva: Kolos.

16. Polupan, Yu. P., 2013. Ontogenetic and breeding regularities formation of economically useful traits of Dairy cattle. Doctor's thesis of Agricultural sciences. Institute of Animals breeding and Genetics NAAS, Chubynske.

17. Polupan, Yu. P. and Koval, T. P., 2006. Zviazok morfolohichnykh osoblyvostei vymia koriv chervonoi molochnoi khudoby z yikhnoiu molochnoiu produktyvnistiu [Relationship of the udder morphological traits of cows of Red dairy cattle with their milk productivity]. Visnyk ahrarnoi nauky, issue 11, pp. 49-52.

18. Prokhorenko, P.N. and Loginov, Zh.G., 1985. Golshtino-frizskaya poroda skota [Holstein-Friesian breed of cattle]. Leningrad: Agropromizdat.

19. Soldatov, A. P., 2001. Golshtinskaya poroda. Polnyy katalog porod domashnikh zhivotnykh [Holstein breed. Complete catalog of pet breeds]. Moskva: Eksmo-Press.

20. Stavetska, R. and Klopenko, N., 2015. Kharakterystyka vymia koriv ukrainskoi chorno-riaboi molochnoi porody za vbyrnoho skhreshchuvannia [Characteristics of the udder of cows Ukrainian Black-and-White dairy cattle at absorbing crossing]. Tvarynnytstvo Ukrainy, no. 12(72), pp. 15-20.

21. Fedorovych, V. V. and Babik, N. P., 2012. Vahovyi ta liniinyi rist koriv chervonoi polskoi porody v umovakh zakhidnoho rehionu Ukrainy [Weight and linear growth of Red Polish cows in the western region of Ukraine]. Naukovyi visnyk Lvivskoho natsionalnoho universytetu veterynarnoi medytsyny ta biotekhnolohii im. S. Z. Hzhytskoho. Lviv, no. 3(60), pp. 199-205.

22. Khmelnychyi, L. M., 2003. Eksteriernyi typ ta produktyvnist koriv ukrainskoi chorno-riaboi molochnoi porody [Conformation type and productivity of cows of Ukrainian Black-and-White dairy breed]. Naukovo-tekhnichnyi biuleten Instytutu tvarynnytstva UAAN. Kharkiv, no. 84, pp. 142-146.

23. Khmelnychyi, L. M., 2007. Otsinka eksterieru tvaryn v systemi selektsii molochnoi khudoby: monohrafiia [Estimation of the animal's conformation in the breeding system of dairy cattle: monograph]. Sumy: "Mriia-1".

24. Khmelnychyi, L. M. and Bardash, D. O., 2019. Indicators longevity of cows Ukrainian Red-and-White dairy breed depending on the share of inheritance of Holstein breed [Pokaznyky dovholittia koriv ukrainskoi chervono-riaboi molochnoi porody zalezhno vid chastky spadkovosti holshtynskoi porody]. Visnyk Sumskoho natsionalnoho ahrarnoho universytetu. Seriia "Tvarynnytstvo", issue 4(39), pp. 13-19. doi: https://doi.org/10.32845/bsnau.lvst.2019.4.2.

25. Khmelnychyi, L. M. and Vechorka, V. V., 2014. Vikova minlyvist koreliatsii mizh nadoiem ta liniinoiu otsinkoiu typu koriv-pervistok ukrainskykh chorno- ta chervono-riaboi molochnykh porid [Age variability of correlations between milk yield and linear assessment of type cows-firstborn of Ukrainian Black- Red-and-White dairy breeds]. Tekhnolohiia vyrobnytstva i pererobky produktiv tvarynnytstva. Zbirnyk naukovykh prats BNAU. Bila Tserkva, no. 1(116), pp. 84-87.

26. Khmelnychyi, L. M. and Vechorka, V. V., 2008. Osoblyvosti budovy tila koriv ukrainskoi chorno-riaboi molochnoi ta holshtynskoi порід [Features of cow's body structure of Ukrainian Black-and-White dairy and Holstein breeds]. Rozvedennia $i$ henetyka tvaryn, issue 42, pp. 318-326.

Khmelnychyii Leontii Mykhailovych, Doctor of Agricultural Sciences, Professor

Karpenko Bogdan Mykolaiovych, graduate student

Sumy National Agrarian University (Sumy, Ukraine) ture indices

Features of the conformation cows of Black-and-White cattle of various origins by measurements and body struc-

Studies on the assessment of cows of Ukrainian Black-and-White dairy and Holstein breeds by measurements of body structure and udder were conducted in the herd of the farm PE "Burynske", Pidlisniv branch of Sumy region. The variability of measurements cows of different origins in the age of lactations dynamics confirmed the intrabreed variability with varying reliability degree of the difference between the indicators of evaluated body structure types. According to the assessment of measurements at the age 
of the first, second, third and older lactation, by the best indicators were distinguished Holstein cows. The variability and level of body structure indices at the present stage of selection in the age dynamics of lactations of cows of Ukrainian Black-and-White dairy and Holstein breed testified about the positive formation dynamic of the conformation of animals this cattle in the direction of dairy type with the best indicators in Holsteins of domestic selection. A comparative analysis of the cows-firstborn of Holstein and Ukrainian Black-and-White dairy breeds by measurments of the udder morphological traits revealed an obvious advantage of Holstein cows. Among the evaluated livestock of Holstein breed, $86 \%$ of cows-firstborn have the desired bath-like udder shape and $92 \%$ have a cylindrical teat shape, which is 5 and 6\% more compared to Ukrainian Black-and-White dairy breed, respectively. Only $3 \%$ of cows have a stepped udder among Holsteins, or $4 \%$ less than among cows of Ukrainian Black-and-White dairy breed. The obtained research results indicate about positive selection effect on the application of further crossing of cows of Ukrainian Black-and-White dairy breed by Holstein sires, which will lead to improved development of body structure and udder in their offspring.

Key words: Holstein, Ukrainian Black-and-White dairy, cows, conformation, measurements, body structure, udder

Дата надходження до редакції: 25.10.2021 р. 